\title{
Current infection control practices used in Australian and New Zealand cystic fibrosis centers
}

Rebecca Elizabeth Stockwell ${ }^{1,2}$ (D) Michelle ELizabeth Wood ${ }^{1,2,3}$ (D), Emma Ballard ${ }^{4}$ (D) Vanessa Moore ${ }^{3}$ (D) Claire Elizabeth Wainwright ${ }^{2,5}$ (D) and Scott Cameron Bell ${ }^{1,2,3^{*}}$ (i)

\begin{abstract}
Background: The 2013 update of the Infection Prevention and Control (IP\&C) Guideline outlined recommendations to prevent the spread of CF respiratory pathogens. We aimed to investigate the current infection control practices used in Australian and New Zealand (NZ) CF centers.

Methods: Two online surveys were distributed to Australian and NZ CF centers regarding the uptake of selected IP\&C recommendations. One survey was distributed to all the Medical Directors and Lead CF Nurses and the second survey was distributed to all the Lead CF Physiotherapists.

Results: The response rate was 60\% (60/100) for medical/nursing and 58\% (14/24) for physiotherapy. Over 90\% (55/60) of CF centers followed CF-specific infection control guidelines and consistent infection control practices were seen in most CF centers; 76\% (41/54) had implemented segregation strategies for ambulatory care and no CF centers housed people with CF in shared inpatient accommodation. However, the application of contact precautions (wearing gloves and apron/ gown) by healthcare professionals when reviewing a CF person was variable between CF center respondents but was most often used when seeing CF persons with MRSA infection in both ambulatory care and hospital admission (20/50, $40 \%$ and $42 / 45$, 93\% of CF centers, respectively). Mask wearing by people with CF was implemented into 61\% (36/59) of centers. Hospital rooms were cleaned daily in 79\% (37/47) of CF centers and the ambulatory care consult rooms were always cleaned between consults (49/49, 100\%) and at the end of the clinic session (51/51, 100\%); however the staff member tasked with cleaning changed with 37\% (18/49) of CF centers responding that CF multidisciplinary team (MDT) members cleaned between patients whereas at the end of the clinic session, only 12\% (6/51) of the CF MDT cleaned the consult room.

Conclusions: Overall, Australian and NZ CF centers have adopted many recommendations from the IP\&C. Although, the application of contact precautions was inconsistent and had overall a low level of adoption in CF centers. In 25\% of centers, mixed waiting areas occurred in the ambulatory care. Given the variability of responses, additional work is required to achieve greater consistency between centers.
\end{abstract}

Keywords: Cystic fibrosis, Infection control, Cross-infection, Contact precautions, Survey, Masks, Cleaning

\footnotetext{
* Correspondence: scott.bell@health.qld.gov.au

Data in this manuscript was presented at the Thoracic Society of Australia and New Zealand Society of Respiratory Science (TSANZSRS) Conference held March, 2018 in Adelaide, and at the TSANZSRS Conference held March, 2019 in Gold Coast, Australia.

'Lung Bacteria Group, QIMR Berghofer Medical Research Institute, 300

Herston Road, Herston, QLD 4006, Australia

${ }^{2}$ Faculty of Medicine, The University of Queensland, Herston, QLD 4006,

Australia

Full list of author information is available at the end of the article
}

(c) The Author(s). 2020 Open Access This article is distributed under the terms of the Creative Commons Attribution 4.0 International License (http://creativecommons.org/licenses/by/4.0/), which permits unrestricted use, distribution, and reproduction in any medium, provided you give appropriate credit to the original author(s) and the source, provide a link to the Creative Commons license, and indicate if changes were made. The Creative Commons Public Domain Dedication waiver (http://creativecommons.org/publicdomain/zero/1.0/) applies to the data made available in this article, unless otherwise stated. 


\section{Background}

The Infection Recommendations for Patients with Cystic Fibrosis (CF) were initially published in 2003 [1] and recently updated as Infection Prevention and Control (IP\&C) Guideline for CF: 2013 Update [2] in response to the emerging evidence of CF respiratory pathogen transmission. The guidelines outline recommendations to reduce cross-infection in CF centers, although some of the recommendations have been debated in CF medical and lay communities $[3,4]$. Furthermore, the implementation of these recommendations may be limited by logistical, resource and hospital infrastructure constraints.

Recently, the results of a US-based survey about the uptake of the IP\&C guidelines focussing on education and quality improvement activities have been published [5]. The authors reported many of the updated recommendations had been adopted in US CF centers [5] however, the adoption of the IP\&C recommendations outside of the US is unknown. We aimed to investigate the current infection control practices used in Australian and New Zealand CF centers including a focus on logistics of care, mask wear and cleaning.

\section{Methods}

\section{Survey design}

Two online surveys (www.surveymonkey.com) were developed and piloted by members of the Adult Cystic Fibrosis Center, The Prince Charles Hospital (TPCH), Australia. Survey one was distributed to all the Medical Directors and Lead Nurses of Australian and New Zealand CF centers (56 questions, Additional file 1: Figure S1). The medical/nursing survey design did not include a question about discipline information. Survey two was sent to all the Lead Physiotherapists of the same centers (41 questions, Additional file 2: Figure S2). The study was granted approval as a quality assurance activity by TPCH Human Research and Ethics Committee (HREC/ $17 / \mathrm{QPCH} / 33)$. All survey questions were optional.

\section{Survey participants}

Participants were invited via an email link to participate between September and December 2017. The surveys were distributed to 51 Center Directors (Australia, $n=$ 24; New Zealand, $n=27$ ), 49 Lead CF Nurses (Australia, $n=22$; New Zealand, $n=27$ ) and 24 Lead CF Physiotherapists (Australia, $n=23$; New Zealand, $n=1$ ).

\section{Statistical analysis}

SPSS version 22 was used for statistical analysis. Data was summarised as frequency ("/ denominator") and percentage. Comparisons of interest were between pediatric and adult treating services and between $\mathrm{CF}$ centres with $\leq 200$ and $>200$ patients. The center characteristics analysed from the survey responses were: center type (centers providing pediatric CF care, "pediatrictreating" and centers providing adult CF care, "adulttreating"), center size $(\leq 200 \mathrm{CF}$ patients and $>200 \mathrm{CF}$ patients) and site location (Australia, New Zealand, and $\mathrm{CF}$ center of unknown location). Categorical variables were examined using Pearson's Chi-squared test or Fisher's Exact test, as appropriate, and $P$ values $<0.05$ were considered statistically significant.

\section{Results \\ Medical and nursing Response rates and CF center characteristics}

Sixty medical/nursing responses (time to complete survey $\sim 25 \mathrm{~min}$ ) were received out of a possible 100 invited survey participants $(60 \%)$. Identifying whether the response was from medical or nursing staff could not be determined due to the survey design. Furthermore, not all respondents provided site identifiers as this question was optional. As such, all responses to the medical/nursing survey $(n=60)$ were analysed and reported below.

CF centre type Thirty-eight of 60 (63\%) were paediatrictreating (23 provided paediatric services only and 15 provided combined paediatric and adult services) and 22 (37\%) were adult-treating CF centres.

CF centre location Twenty (33\%) responses were Australian, 14 (23\%) were New Zealand and 26 (43\%) were $\mathrm{CF}$ centres of unknown location.

CF centre size Fifty-two (87\%) responses were from CF centres with $\leq 200$ patients while the remaining 8 (13\%) were from CF centres with $>200$ patients. Centre sizes differed between Australia and New Zealand with predominately $(86 \%)$ small centres $(p<0.001)$. Differences between Australia, New Zealand and those of unknown location servicing $\leq 200$ patients were examined and as no differences were identified with the exception of contact precautions during hospital admission and ambulatory care, further analysis between CF centres with $\leq 200$ and $>200$ patients was considered appropriate.

\section{Infection control policies in CF centers}

Overall, 92\% (55/60) of medical/nursing respondents followed CF-specific infection control guidelines. Response rates were similar between center type $(p=0.23)$ and center size $(p=1.00)$ (Table 1$)$.

\section{Contact precautions}

Inpatient care $\mathrm{CF}$ center respondents varied in their approach of healthcare professionals applying contact precautions (gloves and gown/apron) during review of inpatients with $\mathrm{CF}$, according to respiratory microbiological infection 
Table 1 Infection control strategies used

\begin{tabular}{|c|c|c|c|c|c|c|}
\hline & $\begin{array}{l}\text { Pediatric-treating } \\
\text { services }(n=38)\end{array}$ & $\begin{array}{l}\text { Adult-treating } \\
\text { services }(n=22)\end{array}$ & $p$-value & $\begin{array}{l}\leq 200 \text { patients } \\
(n=52)\end{array}$ & $\begin{array}{l}>200 \text { patients } \\
(n=8)\end{array}$ & $p$-value \\
\hline $\begin{array}{l}\text { Implementation of CF-specific } \\
\text { infection control policy, n (\%) }\end{array}$ & $37 / 38(97 \%)$ & $18 / 22(82 \%)$ & 0.23 & $47 / 50(94 \%)$ & $8 / 8(100 \%)$ & 1.00 \\
\hline \multicolumn{7}{|l|}{ Contact precautions } \\
\hline During hospital admission: & & & & NA & NA & NA \\
\hline All people with CF, n (\%) & 6/19 (32\%) & 8/9 (89\%) & 0.013 & & & \\
\hline MRSA infection, $\mathrm{n}(\%)$ & $26 / 29(90 \%)$ & 16/16 (100\%) & 0.54 & & & \\
\hline MRO infection, n (\%) & 15/21 (71\%) & $11 / 12(92 \%)$ & 0.22 & & & \\
\hline During ambulatory care: & & & & NA & NA & NA \\
\hline All people with CF, n (\%) & 4/32 (13\%) & 4/18 (22\%) & 0.44 & & & \\
\hline MRSA infection, $\mathrm{n}(\%)$ & $13 / 32(41 \%)$ & $7 / 18$ (39\%) & 0.90 & & & \\
\hline MRO infection, n (\%) & 9/26 (35\%) & 6/18 (33\%) & 0.93 & & & \\
\hline Patient mask wearing policy & $24 / 37(65 \%)$ & $12 / 22(55 \%)$ & 0.43 & 29/51 (57\%) & $7 / 8(88 \%)$ & 0.13 \\
\hline $\begin{array}{l}\text { Use of face-masks (regardless of } \\
\text { whether mask-policy implemented): }\end{array}$ & & & 1.00 & & & 0.25 \\
\hline Surgical mask, n (\%) & $22 / 30(73 \%)$ & $11 / 14(79 \%)$ & & $27 / 37(73 \%)$ & $6 / 7(86 \%)$ & \\
\hline N95 mask, n (\%) & $2 / 30(7 \%)$ & $1 / 14(7 \%)$ & & $2 / 37(5 \%)$ & $1 / 7(14 \%)$ & \\
\hline $\begin{array}{l}\text { Combination of mask types/other } \\
\text { mask types, n (\%) }\end{array}$ & $6 / 30(20 \%)$ & 2/14 (14\%) & & $8 / 37(22 \%)$ & 0/7 (0\%) & \\
\hline \multicolumn{7}{|l|}{ Segregation strategies } \\
\hline Hospital rooms used: & & & 0.69 & & & 0.21 \\
\hline $\begin{array}{l}\text { Single room with ensuite only, } \\
\mathrm{n}(\%)\end{array}$ & 19/31 (61\%) & $10 / 18(56 \%)$ & & $27 / 43(63 \%)$ & $2 / 6(33 \%)$ & \\
\hline $\begin{array}{l}\text { Combination of room types, } \\
\text { n (\%) }\end{array}$ & 12/31 (39\%) & $8 / 18(44 \%)$ & & $16 / 43(37 \%)$ & $4 / 6(67 \%)$ & \\
\hline During ambulatory care: & & & 0.51 & & & 0.38 \\
\hline $\begin{array}{l}\text { Segregated waiting areas, } \\
\text { n (\%) }\end{array}$ & 28/35 (80\%) & $13 / 19(68 \%)$ & & $36 / 46(78 \%)$ & $5 / 8(63 \%)$ & \\
\hline Communal waiting areas, n (\%) & $7 / 35(20 \%)$ & 6/19 (32\%) & & $10 / 46(22 \%)$ & $3 / 8(38 \%)$ & \\
\hline
\end{tabular}

CF cystic fibrosis, MRO multi-drug resistant, MRSA methicillin-resistant Staphylococcus aureus; ${ }^{\wedge}$ includes isolation rooms also $(n=1$ response), NA not applicable

status. Of the CF center respondents, 50\% (14/28) applied contact precautions when reviewing inpatients regardless of infection type, 93\% (42/45) applied contact precautions when seeing a CF inpatient with MRSA infection and 79\% (26/33) applied contact precautions when seeing a CF inpatient with multi-drug resistant organism (MRO) infection (Burkholderia cepacia complex and Mycobacterium abscessus group). Almost $90 \%$ of adult-treating CF healthcare professionals applied contact precautions when reviewing all people with $\mathrm{CF}$ compared to $32 \%$ of pediatric centers $(p=0.013)$ (Table 1). The uptake of healthcare professionals applying contact precautions was similar between respondents from pediatric-treating and adult-treating CF centers when reviewing a CF inpatient with MRSA or MRO infections (Table 1). In CF centers with $\leq 200$ patients, healthcare professionals applied contact precautions in $89 \%$ of Australian centers, $40 \%$ of New Zealand centers and $20 \%$ of centers with unknown location when seeing all inpatients with CF (Table 2). Similarly, responses from CF centers with $\leq 200$ patients, $100 \%$ of Australian centers, $86 \%$ of New Zealand centers and $60 \%$ of centers with unknown location reported healthcare professionals applying contact precautions when seeing CF inpatients with MRO infection. The uptake of healthcare professionals following contact precautions when reviewing inpatients with MRSA infection was similar between all locations (Australia, New Zealand or unknown location) in CF centers with $\leq 200$ patients.

Ambulatory care Contact precautions were applied by healthcare professionals in $16 \%$ (8/50) of CF centers respondents when seeing all people with CF, 40\% (20/50) of CF center respondents when seeing a CF person with MRSA infection and 34\% (15/44) of CF center respondents when seeing a CF person with MRO infection. The use of contact precautions by healthcare 
Table 2 Use of contact precautions by CF center location (in CF centers $\leq 200$ patients)

\begin{tabular}{|c|c|c|c|c|}
\hline & Australia $(n=15)$ & New Zealand $(n=14)$ & Not specified $(n=23)$ & $p$-value \\
\hline \multicolumn{5}{|l|}{ Contact precautions } \\
\hline \multicolumn{5}{|l|}{ During hospital admission: } \\
\hline All people with CF, n (\%) & 8/9 (89\%) & $2 / 5(40 \%)$ & $2 / 10(20 \%)$ & 0.007 \\
\hline MRSA infection, $\mathrm{n}(\%)$ & 14/14 (100\%) & $9 / 10(90 \%)$ & 14/15 (93\%) & 0.52 \\
\hline MRO infection, n (\%) & $11 / 11(100 \%)$ & $6 / 7(86 \%)$ & $6 / 10(60 \%)$ & 0.030 \\
\hline \multicolumn{5}{|l|}{ During ambulatory care: } \\
\hline All people with CF, n (\%) & $5 / 13(38 \%)$ & 0/13 (0\%) & $2 / 16(13 \%)$ & 0.031 \\
\hline MRSA infection, $\mathrm{n}(\%)$ & 10/13 (77\%) & $3 / 13(23 \%)$ & $6 / 16(38 \%)$ & 0.016 \\
\hline MRO infection, n (\%) & 10/12 (83\%) & $1 / 10(10 \%)$ & 2/14 (14\%) & $<0.001$ \\
\hline
\end{tabular}

professionals was similar between pediatric- and adulttreating CF centers for all people and those with MRSA or MRO infections (Table 1). In CF centers with $\leq 200$ patients, the use of contact precautions was significantly different between site location (country) (Table 2). During ambulatory care, 38\% of Australian CF centers, $0 \%$ of New Zealand centers and 13\% of centers with unknown location applied contact precautions when reviewing all people with CF. During ambulatory review of people with CF and MRSA infection, $77 \%$ of Australian CF center, 23\% of New Zealand centers and $38 \%$ of centers with unknown location applied contact precautions. During ambulatory review of people with CF and MRO infection, $83 \%$ of Australian CF centers, $10 \%$ of New Zealand centers and $14 \%$ of centers with unknown location applied contact precautions.

\section{Segregation of people with cystic fibrosis during hospital visits}

Inpatient accommodation Segregation of people with CF during hospital admissions was universal, with all CF centers responding that inpatients with CF did not share the same room. The types of hospital rooms used during admission were similar between center types and center sizes (Table 1) with 59\% (29/49) of respondents admitting people with CF to a single room with ensuite.

Ambulatory care waiting areas Seventy-six percent (41/54) of CF center respondents used segregation strategies at ambulatory care clinics (Table 1), with 61\% (33/ 54) of respondents directing CF patients to their designated consult room on arrival. Communal waiting areas were used by $24 \%$ (13/54) of CF center respondents. The waiting area types were similar between CF center type and center size (Table 1).

\section{Patient mask-wear policy}

Sixty-one percent (36/59) of CF center respondents had implemented a mask wear policy for people with CF when in communal areas of the hospital. Implementation of patient mask-wear policies were similar between center type and center size (Table 1 ). The mask type was similar across the center type and center size (Table 1). Surgical masks were used in $75 \%(33 / 44)$ of CF centers, N95 masks used in 7\% (3/44) CF centers and other masks types or a combination of masks were used in 18\% (8/44) CF centers (Table 1).

\section{Cleaning}

Inpatient rooms Inpatient rooms were cleaned daily in $79 \%$ (37/47) of CF center respondents. The frequency of patient hospital room cleaning was similar between CF center type and center size (Table 3 ).

Ambulatory clinics All CF center respondents (49/49) reported their ambulatory clinic rooms were cleaned between each CF patient consultations by a hospital staff member and this was similar between center type and center size (Table 3). Specifically, the cleaning was performed by members of the CF multidisciplinary team (MDT) or clinic nursing staff in 78\% (38/49) of CF centers and by cleaning staff in $8 \%(4 / 49)$ of CF centers. At the end of the CF clinic session, all CF center respondents (51/51) reported their clinic rooms were always cleaned by a hospital staff member. The staff member tasked with cleaning was similar between the center types and center size (Table 3). At the end of the ambulatory care session, cleaning staff cleaned the consultation rooms in 61\% (31/51) of CF centers and CF MDT or clinic nursing staff cleaned the consultation rooms in $31 \%(16 / 51)$ of CF centers.

\section{Physiotherapy respondents Response rates and CF center characteristics}

Fourteen physiotherapy responses (time to complete survey $\sim 20 \mathrm{~min}$ ) were received from the 24 invited survey participants (58\%): nine of 14 (64\%) were pediatric- 
Table 3 Cleaning of CF ambulatory clinics and inpatient rooms

\begin{tabular}{|c|c|c|c|c|c|c|c|}
\hline & $\begin{array}{l}\text { All CF centers } \\
(n=60)\end{array}$ & $\begin{array}{l}\text { Pediatric-treating } \\
\text { services }(n=38)\end{array}$ & $\begin{array}{l}\text { Adult-treating } \\
\text { services }(n=22)\end{array}$ & $p$-value & $\begin{array}{l}\leq 200 \text { patients } \\
(n=52)\end{array}$ & $\begin{array}{l}>200 \text { patients } \\
(n=8)\end{array}$ & $p$-value \\
\hline Frequency of room cleaning: & & & & 0.24 & & & 1.00 \\
\hline Daily, n (\%) & $37 / 47(79 \%)$ & $25 / 29(86 \%)$ & $12 / 18(67 \%)$ & & $32 / 42(76 \%)$ & $5 / 5(100 \%)$ & \\
\hline Not daily, n (\%) & $6 / 47(13 \%)$ & $2 / 29(7 \%)$ & 4/18 (22\%) & & $6 / 42(14 \%)$ & $0 / 5(0 \%)$ & \\
\hline Don't know, n (\%) & $4 / 47(9 \%)$ & $2 / 29(7 \%)$ & $2 / 18(11 \%)$ & & $4 / 42(10 \%)$ & $0 / 5(0 \%)$ & \\
\hline \multicolumn{8}{|l|}{ Cleaning of ambulatory rooms } \\
\hline Between patients: & & & & 0.61 & & & 0.23 \\
\hline CF MDT, n (\%) & 18/49 (37\%) & 10/31 (32\%) & 8/18 (44\%) & & $15 / 41(37 \%)$ & $3 / 8(38 \%)$ & \\
\hline Clinic nursing staff, n (\%) & $20 / 49(41 \%)$ & 12/31 (39\%) & $8 / 18(44 \%)$ & & $17 / 41(41 \%)$ & $3 / 8(38 \%)$ & \\
\hline Cleaning staff, n (\%) & $4 / 49(8 \%)$ & $3 / 31(10 \%)$ & $1 / 18(6 \%)$ & & 2/41 (5\%) & $2 / 8(25 \%)$ & \\
\hline Other staff , n (\%) & $7 / 49(14 \%)$ & 6/31 (19\%) & $1 / 18(6 \%)$ & & $7 / 41(17 \%)$ & 0/8 (0\%) & \\
\hline At end of clinic session: & & & & 0.47 & & & 0.41 \\
\hline CF MDT, n (\%) & $6 / 51(12 \%)$ & $3 / 33(9 \%)$ & $3 / 18(17 \%)$ & & 4/43 (9\%) & $2 / 8(25 \%)$ & \\
\hline Clinic nursing staff, n (\%) & $10 / 51(20 \%)$ & $7 / 33(21 \%)$ & $3 / 18(17 \%)$ & & 9/43 (21\%) & $1 / 8(13 \%)$ & \\
\hline Cleaning staff, n (\%) & $31 / 51(61 \%)$ & 19/33 (58\%) & $12 / 18(67 \%)$ & & $27 / 43(63 \%)$ & 4/8 (50\%) & \\
\hline Other staff , n (\%) & 4/51 (8\%) & 4/33 (12\%) & 0/18 (0\%) & & $3 / 43(7 \%)$ & 1/8 (13\%) & \\
\hline
\end{tabular}

CF cystic fibrosis, MDT multidisciplinary team

treating (5 provided pediatric services only and 4 provided combined pediatric and adult services) and 5 (36\%) were adult-treating CF centers.

\section{Contact precautions}

Infection control in the gym The types of gym sessions used (individual or group sessions) were similar between pediatric- and adult-treating CF center respondents (Table 4). Individual sessions were used in 93\% (13/14) CF centers (Table 4). The gym was always cleaned between patients and the staff member tasked with cleaning was similar between pediatric- and adult-treating CF center respondents (Table 4). In 43\% (6/14) of CF centers, the gym was cleaned by a physiotherapist only, whereas in $57 \%$ (8/ 14) of CF centers, the gym was cleaned by physiotherapists and other staff (e.g. Allied Health Assistants, cleaning staff). In one CF center (7\%), the patients with CF were encouraged to clean the gym equipment.

\section{Discussion}

The key finding from our study was that almost all respondents from CF centers in Australia and New Zealand had implemented and followed CF-specific infection control guidelines based predominantly on the current IP\&C recommendations [2]. In a recent survey of US CF centers, half of the centers had adopted $\geq 75 \%$ of the selected IP\&C recommendations [5]. While the two surveys (ours and the US) had differing approaches, the key message is that many of the Australian, New Zealand and US CF-centers have implemented infection control strategies based upon the published IP\&C recommendations [2]. The adoption of IP\&C recommendations surveyed in Australian and New Zealand CF centers were similar between center type (pediatrictreating vs adult-treating) and center size ( $\leq 200$ patients vs $>200$ patients), which was similar to the results of the US survey [5]. Regional differences in the adoption of IP\&C recommendations were found in the US-based

Table 4 Infection control strategies used: physiotherapy responses

\begin{tabular}{|c|c|c|c|}
\hline & Pediatric-treating services $(n=9)$ & Adult-treating services $(n=5)$ & $p$-value \\
\hline \multicolumn{4}{|l|}{ Segregation strategies } \\
\hline Gym scheduling: & & & 1.00 \\
\hline Individual sessions, n (\%) & 8/9 (89\%) & $5 / 5(100 \%$ & \\
\hline With other patients (without CF), n (\%) & $1 / 9(11 \%)$ & $0 / 5(0 \%)$ & \\
\hline \multicolumn{4}{|l|}{ Gym cleaning procedures } \\
\hline Between patients: & & & 0.58 \\
\hline Physiotherapy staff only, n (\%) & $3 / 9(33 \%)$ & $3 / 5(60 \%)$ & \\
\hline Physiotherapy and other ${ }^{\&}$ staff, $\mathrm{n}(\%)$ & $6 / 9(67 \%)$ & $2 / 5(40 \%)$ & \\
\hline
\end{tabular}

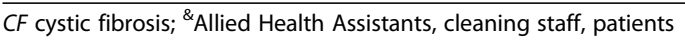


survey [5]; however, we did not analyse the regional differences due to the very different healthcare models used between the two countries: Australia has 24 specialised CF centers that care for $>3400$ people with CF [6] whereas New Zealand has 27 specialised CF centers that care for $\sim 500$ people with CF [7].

Physical barriers were outlined in the current IP\&C to prevent cross-infection in CF centers such as the use of contact precautions and segregation of people with $\mathrm{CF}$ during hospital visits [2]. Contact precaution use was similar between CF center type when reviewing admitted and ambulatory care patients, yet an important finding was the overall low rates for the ambulatory care setting, and that this was greatest in the New Zealand based centers. One exception was that adult-treating CF center respondents applied contact precautions more often when reviewing all CF inpatients compared to their pediatric counterparts. The use of contact precautions in CF centers with $\leq 200$ patients was also more variable. Australian CF center respondents were more likely to follow contact precautions both when reviewing hospitalized and ambulatory care patients. However, reviewing CF inpatients with MRSA infection was an exception and contact precaution use was similar across the different locations; most likely due to established guidelines when caring for any inpatient with MRSA infection [8]. The smaller CF centers and New Zealand centers may not follow the application of contact precautions during ambulatory clinics due to a perceived view of low cross-infection risk; for example, one person with CF may attend an ambulatory clinic session. Overall, the use of contact precautions in Australian and New Zealand CF centers was less common compared to the rates in US CF centers which reported $90 \%$ of centers use contact precautions when reviewing all people with CF (inpatient and ambulatory care settings) [9].

The segregation of people with CF during hospital visits (both inpatient and ambulatory care settings) was adopted in the majority of Australian and New Zealand CF centers despite it being costly and logistically challenging. The use of single rooms with ensuites for inpatient accommodation was lower in Australian and New Zealand CF centers ( 60\%) compared with German CF centers where $81 \%$ of CF inpatients were accommodated in a single room with an adjacent bathroom [10]. Most importantly, no CF center respondents in our study reported people with $\mathrm{CF}$ sharing inpatient rooms with another person with CF. Though in the ambulatory care setting, one-quarter of the CF center respondents continued to use shared waiting areas without formal segregation. Prior studies have demonstrated that enhanced cohort segregation has led to reduced rates of shared strain Pseudomonas aeruginosa infection [11-14]. Our results highlight the potential opportunities for cross-infection in a proportion of CF centers using shared ambulatory care waiting areas.
To prevent cross-infection in CF centers, face masks are recommended to be worn by people with $\mathrm{CF}$ to reduce dispersion of CF respiratory pathogens [2]. The majority (61\%) of Australian and New Zealand CF center respondents had implemented a patient mask-wear policy. While this rate is similar to a recently published study of German CF centers where $60 \%$ supplied masks at the entrance to the ambulatory clinics [10], a US study reported patientmask wear adoption rates of $85 \%$ in inpatient and $87 \%$ in ambulatory settings [9]. The low adoption rates of patientmask wear policies in Australian and New Zealand CF centers is surprising considering hospitals almost universally require people with respiratory illness symptoms to wear a surgical mask while in a hospital facility [8]. However, patient-mask wear policies have been a contentious issue in the CF community [15], which may point to variable uptake of mask wear in CF centers. For those respondents which had implemented a patient-mask wear policy, surgical masks were the most common form of source control used in Australian and New Zealand CF centers. While the IP\&C recommendations do not recommend that respirators be worn by people with $\mathrm{CF}$ as source control [2], a small number $(<10 \%)$ of Australian and New Zealand CF centers did use N95 masks as source control. The low uptake of N95 masks as source control is likely due to the poor comfort of N95 masks reported by people with CF $[16,17]$.

The cleanliness of the hospital environment, frequency of cleaning such as daily cleaning of inpatient rooms [18$20]$ and cleaning of ambulatory care settings [21] has been reported to reduce hospital cross-infections. The implementation of cleaning procedures into CF centers is recommended to prevent CF pathogen acquisition [2]. The majority of CF center respondents from Australia and New Zealand cleaned inpatient rooms on a daily basis and most CF centers cleaned ambulatory care consult rooms both between patients and at the end of the clinic session. In the US survey, more than three-quarters of the ambulatory care rooms were reported to be cleaned [5] although the timing of the cleaning protocol (e.g. between patients, at the end of the day, etc) was not reported.

Our study also surveyed CF physiotherapists about the uptake of the IP\&C recommendations especially the delivery of exercise sessions, an integral component of CF treatment [22]. Physiotherapy respondents delivered gym-based exercise mostly as individual patient sessions. Furthermore, the gyms were cleaned between every patient and the physiotherapist was most often involved in the cleaning (either solely or in combination with other staff). Interestingly, one CF center respondent that the patient assisted with cleaning of the gym equipment and this supports the findings of an earlier study that reported engagement of people with CF may enhance patient adherence to infection control measures [23]. 
The impact on people with CF and their families when implementing these enhanced IP\&C recommendations in CF centers [2] must also be considered. The most recent IP\&C guidelines included consultation with three parents of children with $\mathrm{CF}$ and an adult with $\mathrm{CF}$ along with $\mathrm{CF}$ healthcare experts [2]. While patient engagement in developing and implementing changes to IP\&C guidelines should remain a priority, the knowledge levels in the wider $\mathrm{CF}$ community can vary and ongoing education of the CF community should also be prioritised. Furthermore, the debate in the medical community around appropriate infection control measure to implement in CF centers [3, 4] and the lack of understanding of how CF respiratory pathogens are acquired can heighten anxiety in people with CF and their families $[24,25]$. Some recommendations are accepted into the CF community despite the associated negative consequences. For example, segregation is supported in the CF community, although the psychosocial effects of segregating patients can be considerable [26, 27].

There were a number of limitations to this study. Firstly, all survey questions were optional (including the identifying questions) to enhance honest survey responses which may have resulted in frank feedback about local infection control policies and practices. The same survey was sent to Center Directors' and Lead Nurses' with no identifier to differentiate which discipline responded (medical or nursing). Additionally, the site identifier was an optional question and the majority of medical/nursing respondents did not answer or did not provide sufficient details to identify the individual site. The bias due to responses from both parties on key outcomes is unknown as we cannot assume both parties responded for each CF center. Interpretation of results for center type or center size comparisons has thus always been in reference to the responses reported for each category. Secondly, only $60 \%$ of invited survey participants responded to the survey which may influence the generalisability of the survey results to all CF centers [28]. Thirdly, Australian and New Zealand CF centers function with very different models of care and while care has been taken to remove these influencing factors, it is unable to be eliminated from the data collection, analysis, and interpretation and may have biased the survey results. Finally, the impact of implementing the IP\&C recommendations into CF centres on people with $\mathrm{CF}$ and their families has not been evaluated here and requires additional study, yet is an important aspect in effectively implementing the IP\&C recommendations [5].

\section{Conclusion}

In conclusion, Australian and New Zealand CF centers who responded to this survey have readily adopted many of the IP\&C recommendations and established some consistent infection control strategies. However, the surveys identified areas of inconsistencies between CF centers (e.g., following contact precautions), and highlights opportunities for improvements. Ensuring the implementation of consistent IP\&C recommendations into CF centers is desirable, as this may reduce the risk of cross-infection between people with CF and will likely facilitate the transitioning of care to other CF centers.

\section{Supplementary information}

Supplementary information accompanies this paper at https://doi.org/10. 1186/s12890-020-1052-y.

Additional file 1: Figure S1. Medical/nursing infection control survey.

Additional file 2: Figure S2. Physiotherapy infection control survey.

\section{Acknowledgements}

We thank the staff from the CF centers in Australia and New Zealand who participated in the survey.

\section{Authors' contributions}

R.E.S, M.E.W, V. M, C.E.W, and S.C.B conceived and designed the experiment. R.E.S and E.B led the data analysis. R.E.S. and S.C.B. provide overall responsibility for the data and wrote the manuscript, with input from all coauthors. All authors read and approved the final manuscript.

\section{Funding \\ The Cystic Fibrosis Foundation grant (BELL14AO) indirectly supported this project. R.E.S acknowledges The Prince Charles Hospital Foundation and Advance Queensland PhD Scholarships. C.E.W and S.C.B both acknowledge Queensland Health Research Fellowship (HRF. Wainwright and \#50007, respectively). The funding bodies had no role in the study design, the analysis of the data, the preparation of the manuscript, or the decision to publish.}

\section{Availability of data and materials}

The datasets used and/or analysed during the current study are available from the corresponding authors on reasonable request.

\section{Ethics approval and consent to participate}

The study was granted approval as a quality assurance activity by TPCH Human Research and Ethics Committee (HREC/17/QPCH/33) and as such, did not require written consent. Participant consent was implied based on completion of the online survey.

\section{Consent for publication}

All authors read and approved the final manuscript.

Competing interests

The authors declare that they have no competing interests.

\section{Author details}

${ }^{1}$ Lung Bacteria Group, QIMR Berghofer Medical Research Institute, 300 Herston Road, Herston, QLD 4006, Australia. Faculty of Medicine, The University of Queensland, Herston, QLD 4006, Australia. ${ }^{3}$ Adult Cystic Fibrosis Center, The Prince Charles Hospital, 627 Rode Road, Chermside, QLD 4032, Australia. ${ }^{4}$ Statistical Support Group, QIMR Berghofer Medical Research Institute, 300 Herston Road, Brisbane, QLD 4006, Australia. ${ }^{5}$ Respiratory and Sleep Medicine, Queensland Children's Hospital, 501 Stanley Street, South Brisbane, QLD 4101, Australia.

Received: 26 March 2019 Accepted: 10 January 2020

Published online: 17 January 2020

\section{References}

1. Saiman L, Siegel J. Infection control recommendations for patients with cystic fibrosis: microbiology, important pathogens, and infection control 
practices to prevent patient-to-patient transmission. Infect Control Hosp Epidemiol. 2003;24(Suppl 5):S6-52.

2. Saiman L, Siegel JD, LiPuma JJ, Brown RF, Bryson EA, Chambers MJ, Downer VS, Fliege J, Hazle LA, et al. Infection prevention and control guideline for cystic fibrosis: 2013 update. Infect Control Hosp Epidemiol. 2014;35(Suppl 1): S1-S67.

3. Jain M, Saiman LM, Sabadosa K, LiPuma JJ. Point: does the risk of cross infection warrant exclusion of adults with cystic fibrosis from cystic fibrosis foundation events? Yes. Chest. 2014;145(4):678-80

4. Shepherd SL, Goodrich EJ, Desch J, Quinton PM. Counterpoint: does the risk of cross infection warrant exclusion of adults with cystic fibrosis from cystic fibrosis foundation events? No. Chest. 2014;145(4):680-3.

5. Saiman L, Zhou JJ, Jiang X, Kosorok MR, Muhlebach MS. Surveying cystic fibrosis care centers to assess adoption of infection prevention and control recommendations. Infect Control Hosp Epidemiol. 2018;39(6):647-51.

6. Ruseckaite R, Ahern S, Ranger T, Tacey M, Dean J, Gardam M, Bell S, Burke N. Australian Cystic Firbosis Data Registry. In: The Australian Cystic Fibrosis Data Registry Annual Report, 2016; 2018.

7. Cystic fibrosis NZ. Cystic fibrosis NZ. Available from: www.cfnz.org.nz (last accessed: 29th January 2019).

8. Siegel JD, Rhinehart E, Jackson M, Chiarello L. 2007 guideline for isolation precautions: preventing transmission of infectious agents in health care settings. Am J Infect Control. 2007:35(10 Suppl 2):S65-164.

9. Stoudemire W, Jiang X, Zhou JJ, Maykowski P, Kosorok MR, Muhlebach MS, Saiman L, et al. Am J Infect Control. 2019. https://doi.org/10.1016/j.ajic.2019.03.015.

10. Meyer S, Nusslein T, Nahrlich L, Bend J, Gartner B, Becker SL, Simon A. Infection prevention and control in patients with cystic fibrosis (CF): Results from a survey in 35 German CF treatment centers. J Cyst Fibros. 2019. https://doi.org/10.1016/j.jcf.2019.10.012.

11. Kevat A, Carzino R, Massie J, Harrison J, Griffiths AL. Elimination of Australian epidemic strain (AES1) Pseudomonas aeruginosa in a pediatric cystic fibrosis center. Pediatr Pulmonol. 2018:53(11):1498-503.

12. van Mansfeld R, de Vrankrijker A, Brimicombe R, Heijerman $H$, Teding van Berkhout F, Spitoni C, Grave S, van der Ent C, Wolfs T, et al. The effect of strict segregation on Pseudomonas aeruginosa in cystic fibrosis patients. PLoS One. 2016:11(6):e0157189.

13. Griffiths AL, Wurzel DF, Robinson PJ, Carzino R, Massie J. Australian epidemic strain Pseudomonas (AES-1) declines further in a cohort segregated cystic fibrosis clinic. J Cyst Fibros. 2012;11(1):49-52.

14. Griffiths AL, Jamsen K, Carlin JB, Grimwood K, Carzino R, Robinson PJ, Massie J, Armstrong DS. Effects of segregation on an epidemic Pseudomonas aeruginosa strain in a cystic fibrosis clinic. Am J Respir Crit Care Med. 2005;171(9):1020-5.

15. Smyth AR, Smith SJ, Rowbotham NJ. Pro con debate - infection prevention and control in cystic fibrosis: one size fits all the argument against. Paediatr Respir Rev. 2019. https://doi.org/10.1016/j.prrv.2019.08.001.

16. Stockwell RE, Wood ME, He C, Sherrard LJ, Ballard EL, Kidd TJ, Johnson GR, Knibbs $L D$, Morawska $L$, et al. Face masks reduce the release of Pseudomonas aeruginosa cough aerosols when worn for clinically relevant periods. Am J Respir Crit Care Med. 2018;198(10):1339-42.

17. Wood ME, Stockwell RE, Johnson GR, Ramsay KA, Sherrard L, Jabbour N, Ballard E, O'Rourke P, Kidd TJ, et al. Face masks and cough etiquette reduce the cough aerosol concentration of Pseudomonas aeruginosa in people with cystic fibrosis. Am J Respir Crit Care Med. 2018;197(3):348-55.

18. Barker AK, Alagoz O, Safdar N. Interventions to reduce the incidence of hospital-onset Clostridium difficile infection: an agent-based modeling approach to evaluate clinical effectiveness in adult acute care hospitals. Clin Infect Dis. 2018;66(8):1192-203.

19. Sitzlar B, Deshpande A, Fertelli D, Kundrapu S, Sethi AK, Donskey CJ. An environmental disinfection odyssey: evaluation of sequential interventions to improve disinfection of Clostridium difficile isolation rooms. Infect Control Hosp Epidemiol. 2013;34(5):459-65.

20. Hess AS, Shardell M, Johnson JK, Thom KA, Roghmann MC, Netzer G, Amr S, Morgan DJ, Harris AD. A randomized controlled trial of enhanced cleaning to reduce contamination of healthcare worker gowns and gloves with multidrugresistant bacteria. Infect Control Hosp Epidemiol. 2013;34(5):487-93.

21. Hefzy EM, Wegdan AA, Abdel Wahed WY. Hospital outpatient clinics as a potential hazard for healthcare associated infections. J Infect Public Health. 2016:9(1):88-97.

22. Cox NS, Holland AE. Current perspectives of physical activity in cystic fibrosis. Expert Rev Respir Med. 2018. https://doi.org/10.1080/17476348.2019. 1552833.
23. Miroballi Y, Garber E, Jia H, Zhou JJ, Alba L, Quittell LM, Angst D, Cabana M, Saiman L. Infection control knowledge, attitudes, and practices among cystic fibrosis patients and their families. Pediatr Pulmonol. 2012;47(2):144-52.

24. Palser SC, Rayner OC, Leighton PA, Smyth AR. Perception of first respiratory infection with Pseudomonas aeruginosa by people with cystic fibrosis and those close to them: an online qualitative study. BMJ Open. 2016;6(12):e012303.

25. Shearing V, Duff AJ, Denton M. Mycobacterium abscessus in people with cystic fibrosis: considerations for psychosocial care. Lancet Respir Med. 2015; 3(11):832-4.

26. Russo K, Donnelly M, Reid AJ. Segregation - the perspectives of young patients and their parents. J Cyst Fibros. 2006;5(2):93-9.

27. Griffiths AL, Armstrong D, Carzino R, Robinson P. Cystic fibrosis patients and families support cross-infection measures. Eur Respir J. 2004;24(3):449-52.

28. Fincham JE. Response rates and responsiveness for surveys, standards, and the journal. Am J Pharm Educ. 2008;72(2):43.

\section{Publisher's Note}

Springer Nature remains neutral with regard to jurisdictional claims in published maps and institutional affiliations.

\section{Ready to submit your research? Choose BMC and benefit from:}

- fast, convenient online submission

- thorough peer review by experienced researchers in your field

- rapid publication on acceptance

- support for research data, including large and complex data types

- gold Open Access which fosters wider collaboration and increased citations

- maximum visibility for your research: over $100 \mathrm{M}$ website views per year

At BMC, research is always in progress.

Learn more biomedcentral.com/submissions 